\title{
ANALISIS PENERAPAN MODEL UTAUT (UNIFIED THEORY OF ACCEPTANCE AND USE OF TECHNOLOGY) TERHADAP PERILAKU PENGGUNA SISTEM INFORMASI (STUDI KASUS: SISTEM INFORMASI AKADEMIK PADA STTNAS YOGYAKARTA)
}

\author{
${ }^{1}$ Trie Handayani, ${ }^{2}$ Sudiana \\ ${ }^{1,2}$ Teknik Elektro \\ Sekolah Tinggi Teknologi Nasional \\ Jalan Babarsari, Caturtunggal, Depok, Sleman, Yogyakarta \\ 1nonoi_18172@yahoo.com
}

\begin{abstract}
The appears of the popularity of web technologies and applications have created a vast opportunity for organizations, including institutions of higher education. With the presence of Academic information systems (SiAkad) that is in STTNAS, then do some research to find out the intention of the behavior in the use of Academic information systems using the UTAUT model (Unified Theory Of Acceptance And Use Of Technology). The phenomenon underlying this study is: not yet optimal use of Academic information systems by civitas academic (professors, students and employees) in the process of learning and socializing, so the existence of maximal and haven't yet SiAkad his crisp utilization impact of its use for the entire civitas academic. The study was limited in its scope: the analysis of the influence of Performance Expextancy, Expextancy Effort, Social Influence and Facilitating Condition against the intention SiAkad usage behavior in STTNAS in Yogyakarta. The data in the study on the test with the SEM analysis tool (Structural Equation Modeling). SEM is a tool of statistical analysis that are used to complete the research of multilevel models simultaneously. SEM can be used to solve equations with variables that make up the path.

Research results based on the analysis and discussion is a variable Performance Expectancy (PE), Social Influence (SI) and Facilitating Condition (FC) effect significantly to Behavioral Intention, while variable Effort Expectancy (EE) provides results that are not significant. Fourth overall Predictor is only able to explain the impact on behavioral intention of 37,6 percent.
\end{abstract}

Keywords: user behavior, UTAUT academic information systems

\section{Abstrak}

Kemunculan popularitas teknologi web dan aplikasinya telah membuat peluang yang luas untuk organisasi, termasuk lembaga pendidikan tinggi. Dengan adanya Sistem Informasi Akademik (SiAkad) yang ada di STTNAS, maka dilakukan penelitian untuk mengetahui niat perilaku dalam penggunaan Sistem Informasi Akademik menggunakan model UTAUT (Unified Theory Of Acceptance And Use Of Technology). Fenomena yang mendasari penelitian ini adalah belum optimalnya penggunaan Sistem Informasi Akademik oleh civitas 
akademik (dosen, mahasiswa dan karyawan) dalam proses pembelajaran dan sosialisasi, sehingga keberadaan SiAkad belum maksimal dan belum terukurnya pemanfaatan dampak penggunaannya untuk seluruh civitas akademik. Penelitian ini dibatasi dalam ruang lingkup: analisis pengaruh Performance Expectancy, Effort Expectancy, Social Influence dan Facilitating Condition terhadap niat perilaku dalam penggunaan SiAkad di STTNAS Yogyakarta. Data dalam penelitian diuji dengan alat analisis SEM (Struktural Equation Model). SEM adalah alat analisis statistik yang dipergunakan untuk menyelesaikan model penelitian bertingkat secara serempak. SEM dapat dipergunakan untuk menyelesaikan persamaan dengan variabel yang membentuk jalur (path)

Hasil penelitian berdasarkan analisis dan pembahasan adalah variabel Performance Expectancy (PE), Social Influence (SI) dan Facilitating Condition (FC) berpengaruh secara signifikan terhadap Behavioral Intention, sedangkan variabel Effort Expectancy (EE) memberikan hasil yang tidak signifikan. Secara keseluruhan keempat prediktor tersebut hanya mampu menjelaskan pengaruh terhadap behavioral intention sebesar 37,6 persen.

Kata kunci: perilaku pengguna, UTAUT, Sistem Informasi Akademik.

\section{Pendahuluan}

Pentingnya penggunaan teknologi informasi mulai disadari oleh organisasi modern, terutama dalam era globalisasi di mana perusahaan dituntut untuk semakin kompetitif dan berdaya saing. Oleh karena itu menjadi penting untuk memacu tingkat pemanfaatan dan penggunaan teknologi informasi di organisasi. Keberadaan teknologi informasi tidak bisa dilepaskan peranannya dalam proses pengerjaan tugas karyawan.

Penggunan sistem informasi pada organisasi saat ini telah mengalami peningkatan. Hal ini disampaikan oleh Westland dan Clark (2000) dalam Handayani (2005) bahwa penggunaan sistem dalam organisasi meningkat secara dramatis. Peningkatan ini selain dikarenakan tuntutan organisasi modern, juga disebabkan oleh masyarakat yang haus akan informasi. Sistem informasi akan membantu organisasi untuk menyajikan informasi secara cepat, akurat dan terbuka seperti yang diharapkan oleh masyarakat. Masyarakat saat ini mempunyai pemikiran maju yang lambat laun akan meninggalkan cara-cara manual dan membuat terobosan baru untuk mendapatkan informasi. Akan tetapi, perlu disadari bahwa pembangunan suatu sistem informasi pada organisasi memerlukan investasi biaya yang tidak sedikit. Oleh karena itu, dalam proses pembangunan sistem informasi diperlukan perencanaan yang matang sehingga sistem informasi akan berkeja sesuai kebutuhan dan terintegrasi dengan baik.

Penggunaan sistem informasi selain memberikan banyak manfaat, ada juga organisasi yang gagal dalam penerapannya. Banyak proyek pengembangan sistem telah gagal menghasilkan sistem yang bermanfaat. Kegagalan penerapan sistem teknologi informasi pada organisasi dapat disebabkan oleh beberapa faktor baik internal maupun eksternal (Davis, 1989). Keputusan untuk mengadopsi suatu sistem teknologi informasi ada ditangan manajer, tetapi keberhasilan penggunaan teknologi tersebut tergantung pada penerimaan dan penggunaan setiap individu pemakainya (Hartono, 2007). Perilaku pemakai sistem terbentuk dari sikap dan persepsi pemakai terhadap sistem informasi tersebut.

Sistem Informasi Akademik (SiAkad) berbasis web yang dikenalkan kepada pengguna di STTNAS Yogyakarta diterapkan untuk membantu penyelenggaraan kegiatan akademik bagi civitas akademik (user) di STTNAS Yogyakarta. User dapat memanfaatkan SiAkad untuk melakukan aktivitas pembelajaran pada semester yang akan belangsung sesuai 
dengan jumlah dan ketentuan yang berlaku. Dengan adanya SiAkad diharapkan kepada semua pengguna dapat berperan aktif dalam proses penggunaannya, karena suatu sistem informasi dapat dikatakan berhasil jika sistem informasi tersebut dapat digunakan dengan mudah dan dapat memenuhi kebutuhan pengguna. Untuk mengetahui seberapa besar pengaruh penggunaan dari sistem informasi akademik yang ada di STTNAS, maka dilakukan penelitian dengan judul Analisis Penerapan Model UTAUT (Unified Theory Of Acceptance And Use Of Technology) Terhadap Perilaku Pengguna Sistem Informasi. Dalam kemajuan teknologi informasi saat ini terdapat dua pilihan metode yang digunakan untuk mengukur hal tersebut, yaitu TAM (Technology Acceptance Model) dan UTAUT (The Unified Theory of Acceptance and Use of Technology).

UTAUT merupakan sebuah model untuk menjelaskan perilaku pengguna terhadap teknologi informasi (Venkatesh, dkk, 2003). Model ini merupakan kombinasi dari delapan model yang telah berhasil dikembangkan sebelumnya. Model UTAUT menunjukan bahwa niat untuk berperilaku (behavioral intention) dan perilaku untuk menggunakan suatu teknologi (use behavior) dipengaruhi oleh harapan akan kinerja (performance expectancy), harapan akan usaha (effort expectancy), pengaruh sosial (social influence), dan kondisi pendukung (facilitating conditions). Keempat Faktor tersebut dimoderasi oleh faktor jenis kelamin (gender), usia (age), pengalaman (experience) dan kesukarelaan menggunakan (voluntariness of use). Studi empiris yang mengadopsi model ini telah banyak dilakukan, dan mendapatkan temuan yang beragam.

Dalam penelitian ini akan dibahas pengaruh performance expectancy, effort expectancy, social influence dan facilitating condition terhadap perilaku penggunaan sistem informasi akademik. Diharapkan dengan menerapkan model UTAUT dapat menjelaskan perilaku pengguna SiAkad. Dengan demikian pimpinan STTNAS dapat merumuskan kebijakan yang tepat terkait pemanfaatan SiAkad. Namun untuk menyesuaikan dengan situasi dan kondisi lingkungan penelitian, dalam penelitian ini peneliti tidak menggunakan variabel moderator.

\section{Landasan Teori}

Dari berbagai model mengenai penerimaan user terhadap teknologi yang ada, model Technologi Acceptance Model (TAM) adalah model yang paling sering digunakan (Shin, 2009; Lee, dkk, 2010). Meskipun sudah dilakukan penelitian untuk validasi terhadap kemampuannya memperkirakan penggunaan sistem informasi (Davis, 1986; Davis, dkk, 1989; Davis dan Venkatesh, 1996) TAM memiliki keterbatasan seperti yang dirangkum oleh Lee dkk. Menurut Malhotra dan Galletta (1999), TAM kurang lengkap karena tidak mempertimbangkan satu faktor penting, yaitu pengaruh sosial dalam pemakaian dan pemanfaatan teknologi baru. TAM juga tidak mempertimbangkan adanya halangan yang mencegah individu untuk menggunakan sistem tertentu yang sebenarnya ingin dipakainya (Mathieson, dkk, 2001). Pengembangan dari TAM adalah Unified Theory of Acceptance and Utilization of Technology (UTAUT). UTAUT dibangun oleh Venkatesh, dkk (2003) sebagai gabungan (unified) dari delapan model penerimaan yang sudah ada dan sudah terpublikasi, yaitu Theory of Reason Action (TRA), Technology Acceptance Model (TAM), Theory of Planned Behaviour (TPB), Combined TAM and TPB (C-TAM-TPB), Innovation Diffusion Theory (IDT), Social Cognitive Theory (SCT), Motivational Model (MM), dan Model of PC Utilization (MPCU). 


\subsection{Model the Unified Theory of Acceptance and Use of Technology (UTAUT)}

UTAUT merupakan salah satu model penerimaan teknologi terkini yang dikembangkan oleh Venkatesh, dkk. UTAUT menggabungkan fitur-fitur yang berhasil dari delapan teori penerimaan teknologi terkemuka menjadi satu teori. Kedelapan teori terkemuka yang disatukan di dalam UTAUT adalah theory of reasoned action (TRA), technology acceptance model (TAM), motivational model (MM), theory of planned behavior (TPB), combined TAM and TPB, model of PC utilization (MPTU), innovation diffusion theory (IDT), dan social cognitive theory (SCT). UTAUT terbukti lebih berhasil dibandingkan kedelapan teori yang lain dalam menjelaskan hingga 70 persen varian pengguna (Venkatesh, $\mathrm{dkk}$, 2003). Setelah mengevaluasi kedelapan model, Venkatesh, dkk menemukan tujuh konstruk yang tampak menjadi determinan langsung yang signifikan terhadap behavioral intention atau use behavior dalam satu atau lebih di masing-masing model. Konstrukkonstruk tersebut adalah performance expectancy, effort expectancy, social influence, facilitating conditions, attitude toward using technology, dan self-efficacy. Setelah melalui pengujian lebih lanjut, ditemukan empat konstruk utama yang memainkan peran penting sebagai determinan langsung dari behavioral intention dan use behavior yaitu, performance expectancy, effort expectancy, social influence, dan facilitating conditions. Sedangkan yang lain tidak signifikan sebagai determinan langsung dari behavioral intention. Disamping itu terdapat pula empat moderator: gender, age, voluntariness, dan experience yang diposisikan untuk memoderasi dampak dari empat konstruk utama pada behavioral intention dan use behavior. Gambar 1 menampilkan keterkaitan antara determinan-determinan dan moderatormoderator ini.

Tujuan utama penelitian menggunakan UTAUT adalah membantu organisasi untuk memahami bagaimana penggunaan bereaksi terhadap pengenalan teknologi baru (Wang, 2005). Pada awalnya, UTAUT dikembangkan dari Technology Acceptance Model (TAM) pada tahun 2003 dengan empat konstruk yang mempengaruhi niat perilaku untuk menggunakan teknologi yaitu: performance expectancy, effort expectancy, social influence, facilitating conditions. Sampai saat ini UTAUT sudah dikembangkan kembali dari konteks organisasi menjadi konteks konsumen individu yang diberi nama Model UTAUT2 di mana habit, hedonic motivation dan price value ditambahkan sebagai konstruksi baru.

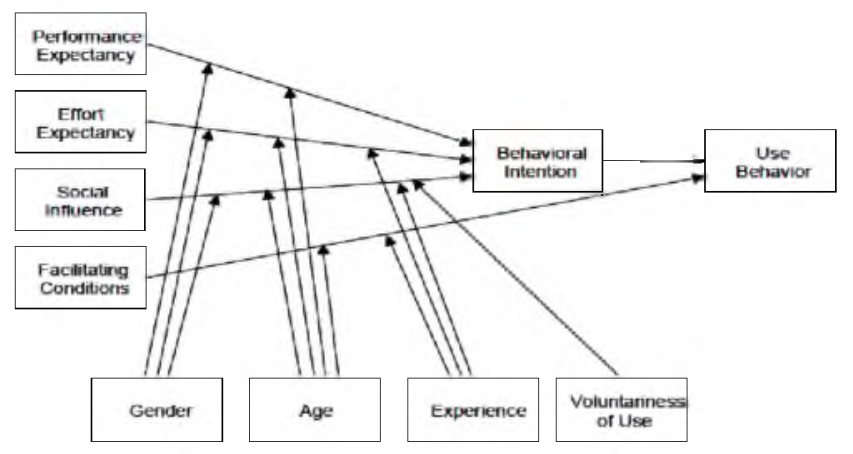

Gambar 1. Model UTAUT (sumber: Venkatesh, dkk, 2003) 


\subsection{SEM (Structural Equation Modelling)}

SEM (Structural Equation Modeling) merupakan teknik analisis yang memungkinkan pengujian sebuah rangkaian hubungan yang relatif rumit secara simultan. Hubungan yang rumit itu dapat dibangun antara satu atau beberapa variabel independen dengan satu atau beberapa variabel dependen. Masing-masing variabel dapat berbentuk faktor atau konstruk yang dibangun dari beberapa indikator. SEM merupakan pendekatan terintegrasi antara dua analisis yaitu analisis faktor dan analisis jalur (path analysis). SEM menggunakan metode statistik untuk menyajikan data dalam pencapaian tujuan penelitian dan dapat menerapkan banyak model dalam menjawab rumusan masalah penelitian.

Berdasarkan konsep tersebut tahap analisis data dengan SEM adalah dengan melakukan 1) uji validitas dan reliabilitas (setara dengan analisis faktor), 2) uji model hubungan antar variabel (path analysis), dan 3) konfirmasi model (SEM). Prosedur SEM secara umum mengandung tahap-tahap sebagai berikut (Bollen dan Long, 1993, dalam Wijanto, 2008):

1. Spesifikasi Model: tahapan ini terkait dengan pembentukan model awal persamaan struktural, sebelum dilakukannya estimasi. Model awal diformulasikan berdasarkan suatu teori atau penelitian-penelitian sebelumnya.

2. Identifikasi: berkaitan dengan pengkajian tentang kemungkinan diperolehnya nilai yang unik untuk setiap parameter yang ada dalam model dan kemungkinan persamaan simultan tidak ada solusinya.

3. Estimasi: berkaitan dengan estimasi terhadap model untuk menghasilkan nilainilai parameter dengan menggunakan salah satu metode estimasi yang tersedia. Pemilihan model estimasi sering kali ditentukan berdasarkan karakteristik dari variabel-variabel yang dianalisis.

4. Uji Kecocokan: merupakan pengujian kecocokan antara model dengan data beberapa kriteria kecocokan atau goodness of fit (GOF).

5. Respesifikasi terkait dengan respesifikasi model berdasarkan hasil kecocokan model tahap sebelumnya.

\subsection{Kerangka Pikir}

Penelitian ini menggunakan sebuah model sebagai kerangka pemikiran teoritis yaitu UTAUT yang digunakan dalam sistem Informasi Akademik (SiAkad). Sesuai dengan ruang lingkup penelitian maka model UTAUT yang digunakan dalam penelitian ini telah dimodifikasi sedemikian rupa, seperti terlihat pada Gambar 1 hingga menjadi lebih sederhana menjadi seperti Gambar 2.

Model penelitian tersebut memberikan gambaran bahwa ada pengaruh sejumlah faktor dari performance expectancy $(\mathrm{PE})$, effort expectancy $(\mathrm{EE})$, social influence (SI), dan facilitating conditions (FC) terhadap Behavioral Intention to Use the System (BIUS) yang selanjutnya akan dianalisis menggunakan alat analisis SEM. 


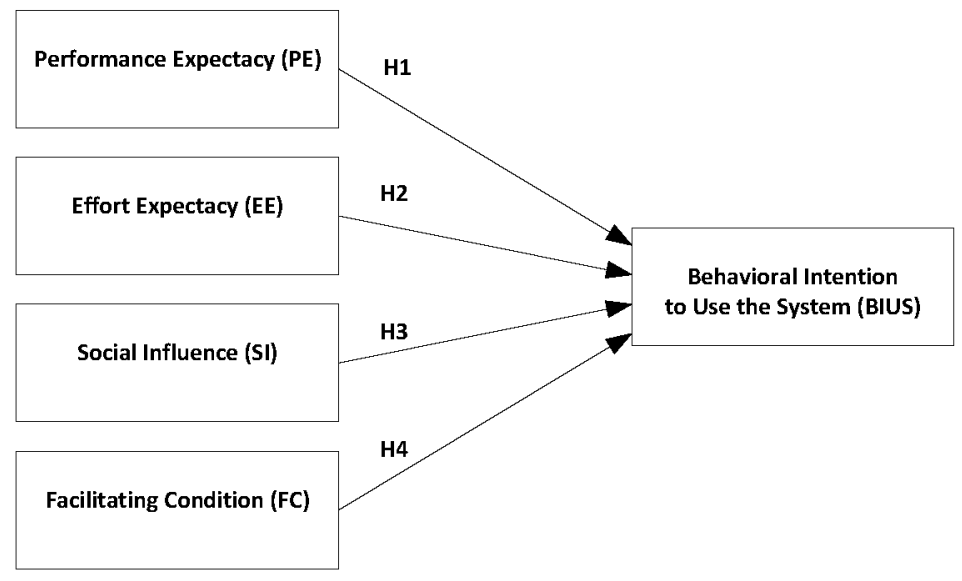

Gambar 2. Model Penelitian

\subsection{Hipotesis}

Penelitian ini melakukan hipotesis tentang hubungan konstruk-konstruk independen yang terdiri dari konstruk PE, konstruk EE, konstruk SI, dan konstruk FC, terhadap konstruk dependen yaitu konstruk BIUS yang didasarkan pada kerangka berfikir, seperti Tabel 1.

Tabel 1. Hipotesis Penelitian

\begin{tabular}{|c|l|}
\hline No & \multicolumn{1}{|c|}{ Hipotesis } \\
\hline H1 & $\begin{array}{l}\text { Ekspektasi kinerja (Performance Expectancy) mempunyai pengaruh positif } \\
\text { terhadap minat dalam menggunakan Sistem Informasi Akademik atau SiAKad } \\
\text { (Behavioral Intention to Use) }\end{array}$ \\
\hline H2 & $\begin{array}{l}\text { Ekspektasi usaha (Effort Expectancy) mempunyai pengaruh positif terhadap } \\
\text { minat pemanfaatan dan penggunaan SiAkad (Behavioral Intention to Use The } \\
\text { System). }\end{array}$ \\
\hline H3 & $\begin{array}{l}\text { Faktor sosial (Social Influence) mempunyai pengaruh positif terhadap minat } \\
\text { pemanfaatan dan penggunaan SiAkad (Behavioral Intention to Use The System). }\end{array}$ \\
\hline H4 & $\begin{array}{l}\text { Kondisi-kondisi Pemfasilitasi (Facilitating Conditions) mempunyai pengaruh } \\
\text { positif terhadap perilaku pemanfaatan dan penggunaan SiAkad (Behavioral } \\
\text { Intention to Use The System). }\end{array}$ \\
\hline
\end{tabular}

\section{Metodologi Penelitian}

Model analisis dalam penelitian ini dapat dilihat pada Gambar 2, di mana terdapat 1 variabel dependen, yaitu Behavioral Intention To Use the System (BIUS) dan 4 variabel independen, yaitu performance expectancy (PE), effort expectancy (EE), social influence (SI), dan facilitating conditions (FC) yang digambarkan dalam bentuk hubungan-hubungan yang akan dianalisis. Sedangkan skala pengukuran yang digunakan pada penelitian adalah skala likert 4 point dengan (1) Sangat Tidak Setuju, (2) Tidak Setuju, (3) Setuju dan (4) Sangat Setuju. Adapun sampel dalam penelitian ini menggunakan teknik Proportionate Stratified Random Sampling. Teknik ini digunakan karena populasinya tidak homogen, mengacu pada pendapat Sugiyono (2010) bahwa, "Proportionate Stratified Random Sampling digunakan bila populasi mempunyai anggota atau unsur yang tidak homogen dan berstrata secara proporsional". Strata yang dimaksudkan dalam penelitian ini yaitu Strata SMA, Diploma 3, S1, S2, S3, angkatan 2010/2011, angkatan 2011/ 2012, dan angkatan 2013/ 2014. Alasan 
teknik ini digunakan peneliti untuk mengambil sampel, disebabkan karena dapat memperkecil galat (errors) penarikan sampel serta meningkatkan peluang setiap strata yang terwakili dalam sampel, selain itu juga agar mendapatkan ketepatan yang lebih tinggi, karena stratifikasi akan menghasilkan presisi yang lebih baik dalam melakukan estimasi terhadap sifat-sifat populasi. Hasil perhitungan jumlah sampel dari seluruh populasi (Dosen, Mahasiswa dan Karyawan) menggunakan rumus Slovin seperti yang ditunjukkan pada Tabel 2 .

Tabel 2. Jumlah Sampel Responden

\begin{tabular}{|c|c|c|}
\hline Responden & Rumus Slovin & Sampel \\
\hline Responden & $\frac{1757}{1757 .(0,05)^{2}+1}$ & 325 \\
\hline
\end{tabular}

Sumber: Data diolah 2015

Sampel yang dihasilkan dari Tabel 2 sebanyak 325 untuk seluruh populasi. Untuk menentukan sampel stratified proposional maka digunakan rumus sample fraction yang hasilnya dapat dilihat pada Tabel 3.

Tabel 3. Jumlah Sampel Responden

\begin{tabular}{|c|l|c|c|}
\hline No & Responden & Sampel Fraction & Jumlah Sampel \\
\hline 1 & Mahasiswa & $\frac{1597}{1757} \times 325$ & 295 \\
\hline 2 & Dosen & $\frac{90}{1757} \times 325$ & 17 \\
\hline 3 & Karyawan & $\frac{70}{1757} \times 325$ & 13 \\
\hline & \multicolumn{3}{|r|}{ Total } \\
\hline
\end{tabular}

Sumber : Data diolah 2015

Dari perhitungan menggunakan rumus sample fraction maka dihasilkan jumlah sampel sebesar 325, dengan 295 sampel mahasiswa., 17 sampel dosen dan 13 sampel karyawan. Tabel 3 menunjukkan bahwa populasi dari masing-masing responden menunjukkan proposional sebesar $20 \%$. Selanjutnya dilakukan perhitungan jumlah sampel bertingkat (berstrarta) dengan cara pengambilan sampel secara proportional random sampling menggunakan rumus alokasi proportional (lihat Persamaan 1).

$$
\mathrm{ni}=\frac{\mathrm{Ni}}{\mathrm{N}} \times \mathbf{n}
$$

dengan,

ni : Jumlah sampel menurut stratum

$\mathrm{n}$ : Jumlah sampel seluruhnya

$\mathrm{Ni}:$ Jumlah populasi menurut stratum

$\mathrm{N}:$ Jumlah populasi seluruhnya

Dari perhitungan dengan menggunakan rumus alokasi proposional dihasilkan jumlah sampel bertingkat (berstrata) seperti yang ditunjukkan pada Tabel 4. 
Tabel 4. Jumlah Sampel Berdasarkan Angkatan/Strata

\begin{tabular}{|c|c|c|c|}
\hline No & Responden & Angkatan/Strata & $\begin{array}{l}\text { Jumlah } \\
\text { Sampel }\end{array}$ \\
\hline \multirow{3}{*}{1} & \multirow{3}{*}{ Mahasiswa } & $2010 / 2011$ & 65 \\
\hline & & $2011 / 2012$ & 127 \\
\hline & & $2012 / 2013$ & 103 \\
\hline \multirow{3}{*}{2} & \multirow{3}{*}{ Dosen } & $\mathrm{S} 1$ & 3 \\
\hline & & $\mathrm{S} 2$ & 13 \\
\hline & & S3 & 1 \\
\hline \multirow{4}{*}{3} & \multirow{3}{*}{ Karyawan } & SMA & 7 \\
\hline & & D3 & 1 \\
\hline & & $\mathrm{S} 1$ & 5 \\
\hline & & Total & 325 \\
\hline
\end{tabular}

Sumber: Data diolah 2015

Karena teknik pengolahan data mengunakan alat analisis SEM yang mensyaratkan jumlah sampel antara $100-400$, maka jumlah sampel dalam penelitian ini dianggap layak/ memadai.

Teknik pengolahan data yang digunakan dalam penelitian ini menggunakan Structural Equation Model (SEM) yang memiliki kemampuan menguji suatu rangkaian hubungan yang kompleks. Software yang digunakan adalah Amos 7.0 dan software SPSS for windows 15.00 untuk keperluan tabulasi data. Ukuran sampel yang harus dipenuhi dalam permodelan ini adalah menggunakan ukuran sampel dengan teknik maximum likelihood estimation. Model analisis yang digunakan dengan batuan software AMOS 7 dapat dilihat pada Gambar 3 .

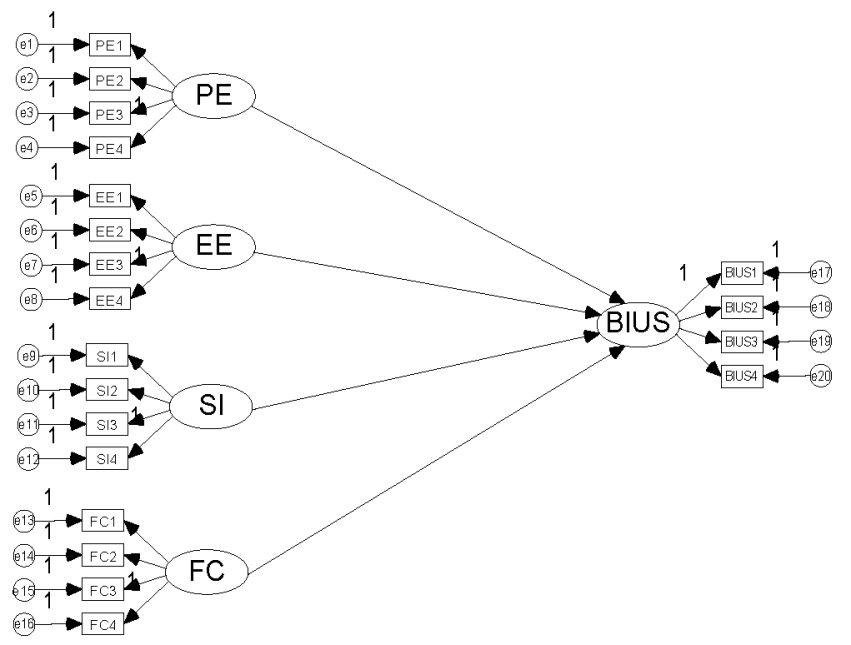

Gambar 3. Analisis Model Persamaan Struktural

\section{Hasil Dan Pembahasan}

Responden dalam penelitian ini adalah Dosen, Mahasiswa dan karyawan. Total kuisioner yang dikirim sebanyak 350 kuisioner. Pengembalian kuisioner yang digunakan sebanyak. 325. Adapun rincian kuisioner dalam penelitian ini ditunjukkan pada Tabel 5. 
Tabel 5. Tingkat Pengembalian Kuisioner

\begin{tabular}{|l|c|}
\hline Keterangan & Jumlah \\
\hline Kuesioner yang dikirim & 350 \\
\hline Kuesioner yang kembali & 330 \\
\hline Kuesioner yang tidak kembali & 20 \\
\hline Kuesioner tidak diisi lengkap & 5 \\
\hline Kuesioner yang dipakai dalam pengolahan data & 325 \\
\hline Tingkat pengembalian & $94,3 \%$ \\
\hline Tingkat pengembalian yang digunakan & $93 \%$ \\
\hline
\end{tabular}

Sumber: Data primer diolah, 2015

Jumlah responden yang memenuhi syarat untuk dianalisis sebanyak 325 dan jumlah seluruh variabel manifes (indikator) adalah 20. Sedangkan rule of thumb untuk perbandingan jumlah sampel terhadap jumlah indikator adalah 1: 5 (Solimun, 2002; Juniarti, 2001). Jadi jika indikator dalam penelitian ini sebanyak 20, maka minimal sampel yang dibutuhkan adalah 100, Menurut Hair, dkk (1998) juga merekomendasikan jumlah sampel ideal untuk SEM adalah 100 - 400. Dengan jumlah responden 325 maka penelitian ini mendukung dilakukannya pengolahan data dengan menggunakan SEM.

Pengujian validitas dilakukan menggunakan program SPSS terhadap 325 responden. Pengambilan keputusan berdasarkan korelasi antara variabel/ item dengan skor total variabel dilihat dari nilai Correlated Item-Total Correlation dibandingkan dengan perbandingan rtabel $=0,113$. Jika nilai $\mathrm{r}$-tabel $<$ rhitung dan bernilai positif maka butir rtabel atau pernyataan tersebut dinyatakan valid.

Hasil pengujian validitas untuk item pernyataan yang digunakan dalam mengukur variabel performance expectance, effort ekspectance, social influence, facilitating condition dan behavioral intention menunjukkan nilai korelasi yang lebih besar dari nilai r-tabel yang ditentukan yakni 0,113 . Dengan demikian dapat dikatakan bahwa seluruh item pernyataan yang digunakan dalam mengukur variabel kemudahan tersebut telah menunjukkan tingkat ketepatan yang cukup baik (valid). Sedangkan pengujian reliabilitas seluruh item yang digunakan dalam mengukur variabel dependent dan independent menghasilkan koefisien reliabilitas (cronbach's alpha) diatas 0,6, sehingga dapat dikatakan bahwa instrumen yang digunakan untuk mengukur seluruh variabel tersebut dinyatakan memiliki reliabilitas yang tinggi. Dengan kata lain instrumen yang digunakan tersebut telah menunjukkan konsistensi pengukuran pada semua respondennya.

Pengujian hipotesis dilakukan dengan teknik analisis regresi linier. Hasil analisis ditunjukkan pada Tabel 6. Berdasarkan analisis, diketahui bahwa variabel Performance Expectancy, Social Influence dan Facilitating Condition berpengaruh secara signifikan terhadap Behavioral Intention, sedangkan variabel Effort Expectancy memberikan hasil yang tidak signifikan. Secara keseluruhan keempat prediktor tersebut hanya mampu menjelaskan pengaruh terhadap behavioral intention sebesar $37,6 \%$. Dengan demikian hasil pengujian hipotesis seperti pada Tabel 7. 
Tabel 6. Hasil Analisis Regresi

\begin{tabular}{|c|l|c|c|c|}
\hline No & Variabel & Beta & T.hitung & Sig. \\
\hline l & Konstanta & & 7,280 & 0,000 \\
\hline 2 & PE & 0,265 & 5,827 & 0,000 \\
\hline 3 & EE & 0,375 & 0,828 & 0,734 \\
\hline 4 & FC & 0,182 & 4,419 & 0,000 \\
\hline 5 & SI & 0,287 & 3,653 & 0,001 \\
\hline & $\begin{array}{l}\mathrm{R}^{2}=0,376, \mathrm{~F}=35,607 \text { signifikan pada } \\
\mathrm{p}<0,01\end{array}$ \\
\hline
\end{tabular}

Tabel 7. Hasil Pengujian Hipotesis Penelitian

\begin{tabular}{|lll|}
\hline \multicolumn{4}{|c|}{ Hipotesis } & Hasil \\
\hline $\mathbf{H}_{\mathbf{1}}$ & $\begin{array}{l}\text { Ekspektasi kinerja (Performance Expectancy) mempunyai } \\
\text { pengaruh positif terhadap minat dalam menggunakan } \\
\text { Sistem Informasi Akademik atau SiAKad (Behavioral } \\
\text { Intention to Use) }\end{array}$ & Diterima \\
\hline $\mathbf{H}_{\mathbf{2}}$ & $\begin{array}{l}\text { Ekspektasi usaha (Effort Expectancy) mempunyai pengaruh } \\
\text { positif terhadap minat pemanfaatan dan penggunaan }\end{array}$ & Ditolak \\
& SiAkad (Behavioral Intention to Use The System). & \\
\hline $\mathbf{H}_{\mathbf{3}}$ & $\begin{array}{l}\text { Faktor sosial (Social Influence) mempunyai pengaruh } \\
\text { positif terhadap minat pemanfaatan dan penggunaan } \\
\text { SiAkad (Behavioral Intention to Use The System). }\end{array}$ & \\
\hline & $\begin{array}{l}\text { Kondisi-kondisi Pemfasilitasi (Facilitating Conditions) } \\
\text { mempunyai pengaruh positif terhadap perilaku pemanfaatan } \\
\text { dan penggunaan SiAkad (Behavioral Intention to Use The }\end{array}$ & Diterima \\
System).
\end{tabular}

Tabel 8. Variabel dan dimensi

\begin{tabular}{|c|l|c|}
\hline Variabel & Dimensi & Notasi \\
\hline \multirow{3}{*}{$\begin{array}{c}\text { Effort Expectacy } \\
\text { (EE) }\end{array}$} & Kemudahan Interaksi & E1 \\
& Kompleksitas & E2 \\
& Persepsi Kemudahan Penggunaan & E3 \\
& Kemudahan untuk dipelajari & E4 \\
\hline \multirow{3}{*}{ Performance } & Persepsi Kemudahan Pengelolaan & PE1 \\
Expectacy (PE) & Kecepatan dalam mengerjakan & PE2 \\
& Keuntungan kinerja & PE3 \\
& Motivasi & PE4 \\
\hline \multirow{5}{*}{ Social Influence (SI) } & Faktor Keluarga & SI1 \\
& Faktor Teman & SI2 \\
& Orang-orang yang berpengaruh & SI3 \\
Facilitating & Kondisi yang menfasilitasi & SI4 \\
\hline Condition (FC) & Pengetahuan & FC1 \\
& Kesesuaian & FC2 \\
& Diterima luas & FC3 \\
\hline \multirow{3}{*}{ Behavioral Intention } & Bermaksud menggunakan lebih sering & FC4 \\
to Use the System & Memprediksi untuk menggunakan & BIUS1 \\
(BIUS) & Berencana menggunakan & BIUS2 \\
& Memiliki kepercayaan yang tinggi dalam & BIUS3 \\
& BIUS4 \\
\hline
\end{tabular}


Pengolahan data dalam penelitian ini menggunakan teknik analisis SEM dengan menggunakan paket program AMOS 7 (analysis of moment structure) dan SPSS. Penggunaan SEM memungkinkan peneliti untuk menguji validitas instrumen penelitian, mengkonfirmasi ketepatan model sekaligus menguji pengaruh suatu variabel terhadap variabel lain. SEM dapat menguji secara bersama-sama (Ghozali, 2006). Teknik analisis SEM yang digunakan antara lain:

1. Pengembangan Model Teoritis: Pengembangan sebuah teori yang berjustifikasi ilmiah merupakan syarat utama menggunakan pemodelan SEM (Ferdinand, 2002). Konstruk dan dimensi yang akan diteliti dari model teoritis diuraikan pada Tabel 8.

2. Diagram Alur: diagram alur penelitian ini menjelaskan lima variabel yaitu PE, EE, SI, FC dan BIUS semuanya adalah variabel latent/ konstruk yaitu variabel yang tidak dapat diukur secara langsung (unobserved). Dari persamaan struktural ini yang merupakan variable independent yaitu PE, EE, SI, dan FC, sedangkan Variabel BIUS merupakan variabel dependent karena variabel ini dipengaruhi oleh variabel sebelumnya. Keberadaan variabel latent diukur oleh indikator-indikator atau variable mantfest (pertanyaan dalam bentuk skala likert). Misalkan variable PE diukur oleh 4 indikator PE1, PE2, PE3, dan PE4 dengan kesalahan pengukuran (error) masing masing e1, e2, e3 dan e4.

3. Persamaan Struktural: Persamaan struktural (SEM) yang dirumuskan untuk menyatakan hubungan kausalitas antar berbagai konstruk.

4. Pemilihan Matriks Input dan Estimasi Model: SEM menggunakan input data yang hanya menggunakan matriks varians atau kovarians atau matrik korelasi untuk keseluruhan estimasi yang dilakukan. Model estimasi standard AMOS adalah menggunakan estimasi maksimum likelihood (ML).

5. Identifikasi Model: Pada hasil output AMOS dapat dijelaskan jumlah sample $n=$ 325 , jumlah data kovarian dapat dihitung dengan menggunakan rumus $p(p+1) / 2$ di mana $p$ adalah jumlah variabel observed (variabel manifest).

6. Uji Kesesuaian (Goodness of Fit): Menguji goodness of fit merupakan tujuan utama dalam persamaan struktural yaitu ingin mengetahui sampai seberapa jauh model yang dihipotesakan "fit" atau cocok dengan sampel data. Hasil uji kesesuaian seperti terlihat pada Tabel 9.

Tabel 9. Hasil Uji Kesesuaian (Goodness of Fit)

\begin{tabular}{|l|c|c|c|}
\hline Goodenss of fit index & Cut of value & Hasil Model & Keterangan \\
\hline$X^{2}$ Chi Square Statistics & Diharapkan kecil & 112,104 & Marginal \\
\hline Significance Probability & $\geq 0,05$ & 0,210 & Fit \\
\hline CMIN/DF & $\leq 2,00$ & 1,650 & Fit \\
\hline GFI & $\geq 0,90$ & |gfi & Fit \\
\hline AGFI & $\geq 0,90$ & agfi & Fit \\
\hline TLI & $\geq 0,95$ & 0,970 & Fit \\
\hline CFI & $\geq 0,95$ & 0,964 & Fit \\
\hline RMSEA & $\leq 0,08$ & 0,020 & Fit \\
\hline
\end{tabular}

Sumber: Data Hasil output AMOS, 2015

7. Interpretasi dan Modifikasi Model: Pengujian terhadap nilai residual mengindikasikan bahwa secara signifikan model yang sudah dimodifikasi tersebut dapat diterima dan uji normalitas dilakukan terhadap data yang digunakan dalam analisis model 
awal secara keseluruhan, dengan menggunakan AMOS versi 7.0. Hasil uji normalitas dapat dilihat dari nilai minimum, maksimum, skewness, kurtosis, critical ratio untuk masing-masing variabel dan total nilai multivariate. Nilai multivariate pada uji normalitas data sebesar 1,962. Nilai tersebut dibawah $\pm 2,58$ (critical ratio pada tingkat signifikansi 0,05 ), sehingga dapat dikatakan bahwa data yang digunakan secara multivariate mempunyai sebaran yang normal.

8. Hasil Estimasi: selanjutnya adalah melakukan estimasi model full struktural yang hanya memasukkan indikator yang telah diuji konstruknya. Hasil output AMOS menunjukkan model telah memenuhi kriteria model fit yaitu ditunjukkan dengan nilai ChiSquare $=112,104$ dengan probability $=0,210$ dan $\mathrm{CMIN} / \mathrm{DF}=1.650$, begitu juga dengan nilai kriteria lainnya seperti $\mathrm{TLI}=0,970$ yang nilainya diatas 0,90 dan juga nilai RMSEA $=0,020$ jauh dibawah kriteria yang disyaratkan kurang dari 0,08 . maka dapat disimpulkan bahwa model persamaan struktural adalah fit. Hasil analisis model persamaan struktural seperti yang terlihat pada Gambar 4.

9. Pengujian Validitas Konvergen (Convergent Validity): Convergent Validity adalah pengujian indikator-indikator suatu konstruk laten yang harus konvergen/share (berbagi) dengan proporsi varian yang tinggi. Penilaian convergent validity dilihat dari nilai factor loading. Tabel 10 menunjukkan nilai factor loading masing-masing konstruk. Berdasarkan Tabel 10 menunjukkan bahwa masing-masing konstruk dalam full model berpengaruh pada signifikansi 0,05 .

10. Pengujian Reliabilitas: Reliabilitas adalah ukuran konsistensi internal dari indikator-indikator sebuah variabel bentukan yang menunjukan derajat sampai di mana masing-masing indikator itu mengindikasikan sebuah variabel bentukan yang umum (Ghozali, 2008). Terdapat dua cara yang dapat digunakan yaitu composite (construct) realibility dan variance extracted. Cut-off value untuk composite (construct) realibility adalah minimal 0,7 dan cut-off value untuk variance extracted adalah minimal 0,5.

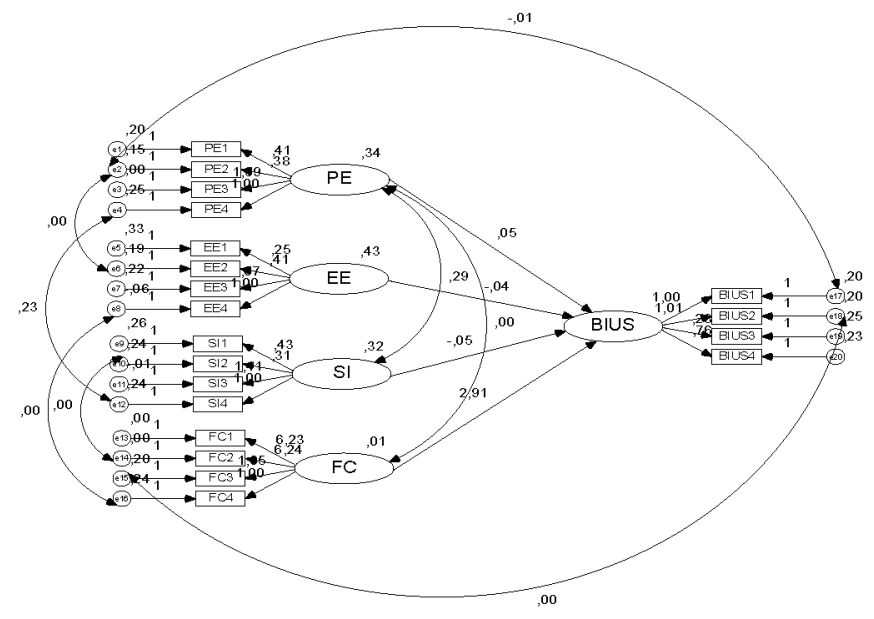

Gambar 4. Full Model Struktural

11. Pengujian Composite (Construct) reliability. Dari hasil perhitungan didapatkan bahwa nilai composite (construct) reliability masing-masing konstruk yaitu:

- BIUS $=0.952165$

- $\mathrm{EE}=0.940874$ 
- $\mathrm{FC}=0.849125$

- $\mathrm{PE}=0.855433$

- SI $=0.898555$

Dari hasil tersebut dapat dilihat bahwa reliabilitas semua konstruk di atas nilai cut-off yaitu 0,70. Hal ini menunjukkan bahwa semua konstruk yang ada dalam full model adalah reliabel.

Tabel 10. Standardized Factor Loading
Konstruk Full Model
\begin{tabular}{|lll|r|}
\hline & & & Estimate \\
\hline BIUS & $<---$ & PE &, 648 \\
BIUS & $<---$ & FC &, 237 \\
BIUS & $<---$ & EE &, 320 \\
BIUS & $<--$ & SI &, 723 \\
PE4 & $<---$ & PE &, 808 \\
PE3 & $<---$ & PE &, 902 \\
PE2 & $<--$ & PE &, 460 \\
PE1 & $<--$ & PE &, 466 \\
EE4 & $<---$ & EE &, 502 \\
EE3 & $<---$ & EE &, 668 \\
EE2 & $<---$ & EE &, 515 \\
EE1 & $<---$ & EE &, 254 \\
SI4 & $<---$ & SI &, 701 \\
SI3 & $<---$ & SI &, 745 \\
SI2 & $<---$ & SI &, 285 \\
SI1 & $<---$ & SI &, 276 \\
FC4 & $<---$ & FC &, 152 \\
FC3 & $<---$ & FC &, 178 \\
FC2 & $<---$ & FC &, 413 \\
FC1 & $<---$ & FC &, 984 \\
BIUS1 <--- & BIUS &, 996 \\
BIUS2 <--- & BIUS &, 338 \\
BIUS3 <--- & BIUS &, 662 \\
BIUS4 <--- & BIUS &, 842 \\
\hline
\end{tabular}

Pengujian Variance Extracted. Variance Extracted memperlihatkan jumlah varians dari indikator yang diekstraksi oleh variabel bentukan yang dikembangkan. Nilai variance extracted yang tinggi menunjukkan bahwa indikator-indikator telah mewakili secara baik variabel bentukan yang dikembangkan (Ghozali, 2008). Dari perhitungan variance extracted masing-masing konstruk yaitu:

$\begin{array}{lll}- \text { BIUS } & =0.869041 \\ - & \text { EE } & =0.799223 \\ \text { - } & \text { FC } & =0.587292 \\ \text { - } & \text { PE } & =0.599899 \\ \text { - } & \text { SI } & =0.690845\end{array}$


Berdasarkan hasil di atas dapat dilihat bahwa variance extracted semua konstruk di atas nilai cut-off yaitu sebesar 0,5 . Hal ini berarti bahwa semua indikator telah mewakili variabel yang ada dalam full model.

\section{Simpulan dan Saran}

\subsection{Simpulan}

Berdasarkan analisis hasil penelitian dan pembahasan pada bagian sebelumnya, maka dapat disimpulkan sebagai berikut:

1. Berdasarkan analisis, diketahui bahwa variabel Performance Expectancy (PE), Social Influence (SI) dan Facilitating Condition (FC) berpengaruh secara signifikan terhadap Behavioral Intention, sedangkan variabel Effort Expectancy (EE) memberikan hasil yang tidak signifikan.

2. Secara keseluruhan keempat prediktor tersebut hanya mampu menjelaskan pengaruh terhadap behavioral intention sebesar $37,6 \%$.

\subsection{Saran}

Bagi peneliti yang ingin melanjutkan penelitian ini disarankan untuk mempertimbangkan beberapa hal, salah satunya adalah menambahkan moderator dalam penelitian sesuai model asli The Unifiedn Theory Of Acceptance and Use Of Technology (UTAUT), yang dapat menjelaskan lebih lanjut atau lebih detail tentang penerapan model ini.

\section{Ucapan Terima Kasih}

Tulisan ini merupakan bagian dari Program Hibah Penelitian Dosen Pemula Tahun 2015 yang dibiayai DIPA Direktorat Penelitian dan Pengabdian Masyarakat, Direktorat Jenderal Pendidikan Tinggi. Ucapan terima kasih kami sampaikan kepada Direktorat Jenderal Pendidikan Tinggi atas kesempatan yang telah kami peroleh. Juga kepada Pimpinan STTNAS Yogyakarta, P3M, dan civitas akademik STTNAS, kami ucapkan terimakasih atas dukungan dan semangatnya. 


\section{Daftar Pustaka}

Arslan, Muhammad. Riaz, Muhammad Assad, 2010. A Roadmap for Usability and User Experience Measurement during early phases of Web Applications Development Thesis.

Cooper, Reimann, Cronin, 2007, The Essentials of Interaction Design, Wiley Publishing Inc.

Davis, F.D., 1989, Perceived usefulness, perceived ease of use, and user acceptance of information technology. MS Quarterly (online), Vol. 13 Iss. 3, pg. 318.

El-Gayar, Omar F., Mark Moran, 2006, College students' acceptance of Tablet PCs: An application of the UTAUT Model, Dakota State University, pg. 2845-2850

Foon, YeohSok., Benjamin Chan Yin Fah, 2011, Internet Banking Adoption in Kuala Lumpur: An Application of UTAUT Model, International Journal of Business and Management. Vol. 6, No. 4. hal. 161-167.

Ghozali, I., 2006, Structural Equation Modeling, Metode Alternatif dengan Partial Least Square. Semarang: Badan Penerbit Universitas Diponegoro.

Hartono, J., 2007, Sistem Informasi Keperilakuan, Penerbit Andi. Yogyakarta.

Handayani, Rini, 2005, Analisis Faktor-Faktor yang Mempengaruhi Minat Pemanfaatan Sistem Informasi dan Penggunaan Sistem Informasi (Studi Empiris Pada Perusahaan Manufaktur di Bursa Efek Jakarta). Jurnal Perpustakaan Universitas Mercubuana. (http://digilib.mercubuana.ac.id), diakses tanggal 8 Agustus 2012.

Nasution, Fahmi Natigor, 2006, Teknologi Informasi Berdasarkan Apek Perilaku (Behavior Ascpect), USU Digital Library, http://library.usu.ac.id (retrieved 16 Januari 2006)

O'Brien, J., 2006, Pengantar Sistem Informasi: Perspektif Bisnis dan Manajerial, Edisi 12, Salemba.

Prasetyo, Hari Basuki., Dian Anubhakti, 2011, Kajian Penerimaan Sistem E-Learning Dengan Menggunakan Pendekatan UTAUT Studi kasus Fakultas Teknologi Informasi Universitas Budi Luhur, Jurnal BIT Vol. 8, No. 2. hal. 45-47.

Sedana, I Gusti Nyoman., St Wisnu Wijaya, 2009, Penerapan Model UTAUT untuk Memahami Penerimaan Dan Penggunaan Learning Management System Studi Kasus: Experential E-Learning Of Sanata Dharma University, Jurnal Sistem Informasi, Vol. 5, No. 2. hal 114-120. 
Trie Handayani, Sudiana 